\title{
THE EFFECT OF SILICON FOLIAR FERTILIZATION IN SUGAR BEET - Beta vulgaris (L.) ssp. vulgaris conv. crassa (Alef.) prov. altissima (Döll)
}

\author{
Arkadiusz ARTYSZAK ${ }^{1,}$, Dariusz GOZDOWSKI', Katarzyna KUCIŃSKA ${ }^{1}$ \\ ${ }^{1}$ Warsaw University of Life Sciences, Department of Agronomy, POLAND \\ ${ }^{2}$ Warsaw University of Life Sciences, Department of Experimental Design and Bioinformatics, POLAND \\ *Corresponding author: arkadiusz_artyszak@sggw.pl
}

Received: 11.12.2014

\begin{abstract}
Presented results are extended continuation study of earlier research (2010-2012) on silicon fertilization effect and comes from the research that was conducted in 2013-2014 in the southeastern region of Poland, in Sahryń $\left(5^{\circ} 41^{\prime} \mathrm{N}\right.$ and $\left.23^{\circ} 46^{\prime} \mathrm{E}\right)$. Two variants of silicon foliar fertilization were tested in sugar beet, Danuśka KWS variety. Two kinds of silicon fertilizers (Herbagreen Basic and Optysil) in 3 stages (in the stage of 4-6 sugar leaf, than a week and two weeks later). One of the silicon fertilizer contained marine calcite and silicon (Ca+Si) and the second one contained silicon ( $\mathrm{Si}$ ) only. Seven variants of foliar fertilization including control variant were tested as total. Foliar fertilization regardless of the kind of fertilizer resulted in increases of: 1) the root yield (for $\mathrm{Ca}+\mathrm{Si}$ variant 10.4-16.2\% and for $\mathrm{Si}$ variant 13.7-15.9\%), 2) biological sugar yield (respectively 11.4-18.1\% and 13.7-15.9\%), 3) technological sugar yield (respectively 12.2-17.7\% and 12.2-15.6\%) compared with the control variant. However the tested variants had no effect for technological root quality compared with the control. A tendencies to decrease content of sodium as a result of foliar fertilizations were observed only.
\end{abstract}

Keywords: Beta vulgaris L.; Biological sugar yield; Roots yield; Sugar content; Technological quality of roots.

\section{INTRODUCTION}

In 2017 in the EU countries the limits of sugar production will be abolished. Such conditions force sugar beet production increase and purchase price reduce at the same time. Therefore the new, more effective solutions for better sugar yield are necessary. However, they must be environmental safe. In many sugar beet studies of a lot attention is paid to the micronutrients foliar fertilization (Pospišil at al. 2005, Kristek et al. 2006, Wróbel and Domaradzki 2006, Hellal et al. 2009, Armin and Asgharipour 2012, Amin et al. 2013, Wróbel and Domaradzki 2013, Artyszak 2014) as well as biostimulators (Černý et al. 2009, Hradecká et al. 2009, Černý et al. 2011, Pačuta 2013, Pačuta and Buday 2013, Pacuta et al. 2013). The foliar fertilization of ground marine rocks mainly containing calcium carbonate $\left(\mathrm{CaCO}_{3}\right)$ and silicon $\left(\mathrm{SiO}_{2}\right)$ is a new issue in fertilization practice. Similarly silicon application is a novel idea of sugar beet fertilization (Artyszak et al. 2014, 2015). The role of silicon in crops is not particularly well understood (Casey et.al. 2003). Silicon plays a very important role in the reduction of the plants vulnerability to biotic and abiotic environmental stress (Fauteux et al. 2005, Mitani and Ma 2005, Ma and Yamaji 2006, Liang et al. 2006, Gunes et al. 2007, Sacała 2009). This component increases the plants' resistance to pathogens and pests (Fawe et al. 1998, Raven 2003, Henriet et al. 2006, Cai et al. 2009). One of the most important beneficial effects of silicon on plant growth is related to increased resistance under water stress conditions (Ma et al. 2004, Sacała 2009). Sugar beet is one of seven plant species that are classified as silicon bio-accumulators (Guntzer et al. 2012). However there is a lack of scientific study on the effectiveness of such fertilization and there is a need to determinate the silicon optimal dose and time of its application.

The aim of the study was to evaluate the effectiveness of different silicon doses applied together or without calcium as foliar fertilization on sugar beet roots yield and technological quality of sugar beet roots.

\section{MATERIALS AND METHODS}

In 2013-2014, the experiment was carried out in the southeastern part of Poland in Sahryń village $\left(50^{\circ} 41^{\prime} \mathrm{N}\right.$ and $23^{\circ} 46^{\prime}$ E). The soil was classified as Chernozem (FAO 2006). Soil condition characteristics are listed in Table 1. The amount of rainfall during growing season (April-October) was $387 \mathrm{~mm}$ in 2013 and $550 \mathrm{~mm}$ in 2014 (Table 2). Two kinds of foliar fertilizers were used. The first one named Herbagreen contained silicon $\left(\mathrm{SiO}_{2}\right)$ 
and calcium $\left(\mathrm{CaCO}_{3}\right)$, the second one named Optysil contained silicon $\left(\mathrm{SiO}_{2}\right)$ mainly. Differentiated silicon and calcium foliar fertilization were the factors of the experiment. The schedule of fertilization variants is placed in Table 3. Both fertilizers were applied one, two or three times during vegetation period. The single dose for Herbagreen Basic was $1.5 \mathrm{~kg} / \mathrm{ha}$, and for Optysil - 0.5 $\mathrm{dm}^{3} /$ ha. The term of the first application was in the growth stage 4-6 sugar beet leaves. The second application was applied one week later and the third two weeks after the first application. In every spraying $250 \mathrm{dm}^{3} /$ ha of water was used. The concentration of Herbagreen Basic was $0.6 \%$ and Optysil $-0.2 \%$. The content of Herbagreen Basic is as follows $(\% \mathrm{~m} / \mathrm{m}): \mathrm{Ca}-26.2, \mathrm{Si}-7.99, \mathrm{Fe}-$ 2.38, $\mathrm{Mg}-1.45, \mathrm{~K}-0.42, \mathrm{Na}-0.37, \mathrm{Ti}-0.3, \mathrm{P}-0.22, \mathrm{~S}$ $-0.16, \mathrm{Mn}-0.08$ and trace amount of $\mathrm{B}, \mathrm{Co}, \mathrm{Cu}$ and $\mathrm{Zn}$. The content of Optysil is: $94.1 \mathrm{~g} \mathrm{Si} \mathrm{i} 24 \mathrm{~g} \mathrm{Fe}$ per one $\mathrm{dm}^{3}$. Both fertilizers are approved for use in organic farming in Poland and they may be used for fertilization of organic sugar beet. Single plot area was $43.2 \mathrm{~m}^{2}$ (for harvest $21.6 \mathrm{~m}^{2}$ ) and number of replication 4 .

Table 1. Content of nutrients in arable layer of the soil in 2013-2014

\begin{tabular}{|c|c|c|c|c|c|c|c|c|c|c|c|c|}
\hline \multirow{2}{*}{ Year } & \multirow{2}{*}{$\begin{array}{l}\mathrm{C}_{\text {org }} \\
\mathrm{g} / \mathrm{kg} \\
\end{array}$} & \multirow{2}{*}{$\mathbf{p H}_{\mathrm{KCl}}$} & \multicolumn{10}{|c|}{$\mathrm{mg} / \mathrm{kg}$} \\
\hline & & & $\mathrm{NO}_{3}{ }^{-}-\mathrm{N}$ & $\mathrm{NO}_{4}{ }^{+}-\mathrm{N}$ & $\mathbf{P}$ & $\mathbf{K}$ & $\mathrm{Mg}$ & B & $\mathrm{Cu}$ & $\mathbf{F e}$ & Mn & $\mathbf{Z n}$ \\
\hline 2013 & 7.54 & 6.70 & 4.75 & 1.09 & 103 & 108 & 74.0 & 1.0 & 2.9 & 690 & 184 & 4.7 \\
\hline 2014 & 11.40 & 7.37 & 11.5 & 4.40 & 21.8 & 74.7 & 87.0 & 7.5 & 6.9 & 660 & 139 & 7.5 \\
\hline
\end{tabular}

Table 2. Weather conditions during vegetation period in 2013-2014

\begin{tabular}{lccc}
\hline & $\mathbf{2 0 1 3}$ & $\mathbf{2 0 1 4}$ & $\mathbf{1 9 9 1 - 2 0 1 4}$ \\
\hline Total rainfall from April to October $(\mathrm{mm})$ & 387 & 550 & 462 \\
Average temperatures from April to October $\left({ }^{\circ} \mathrm{C}\right)$ & 14.8 & 14.5 & $14.3^{*}$ \\
\hline
\end{tabular}

*2002-2014. Source: data from sugar factory Strzyżów, Poland

The forecrop for sugar beet was winter wheat each year. Straw was crushed during harvest and mixed into the topsoil together with nitrogen fertilizer applied at the dose of $40 \mathrm{~kg} \mathrm{~N} / \mathrm{ha}$ with post-harvest tiller. Each autumn phosphorus-potassium fertilizers were applied and covered by deep winter plough. The doses of phosphorous and potassium were determined in accordance with the recommendations based on available phosphorus and potassium content in the soil, and the expected root yields. Each spring nitrogen fertilizers were applied, and mixed into the soil with cultivator. Nitrogen was also used as top dressing fertilization at the stage of sugar beet plants 4-6 leaf (BBCH 14-16). Beets were sown on following dates: April 22, 2013; and March 29, 2014. Row spacing was $0.45 \mathrm{~m}$, distance in the row was $0.21 \mathrm{~m}$, and sowing depth 0.02-0.025 m. Danuśka KWS variety represents the sugar (C) type. Weed control and diseases protection were applied with pesticides recommended by the Institute of Plant Protection National Research Institute in Poznań (Poland). Beet harvesting was carried out on: October 9, 2013; and October 2, 2014 and the time of growing seasons was 170 and 187 days, respectively.

Table 3. Variants of fertilizations applied in the experiment

\begin{tabular}{lcccc}
\hline \multirow{2}{*}{ Variant } & \multicolumn{3}{c}{ Terms of applications/doses, g/ha } & The total dose, g/ha \\
\cline { 2 - 5 } & $\begin{array}{c}\text { 4-6 leaf stage } \\
\text { (BBCH 14-16) }\end{array}$ & A week later & Two weeks later & - \\
\hline 0 & - & - & - & $\mathrm{Ca}-393, \mathrm{Si}-120$ \\
1 & $\mathrm{Ca}-393, \mathrm{Si}-120$ & $\mathrm{Ca}-393, \mathrm{Si}-120$ & $\mathrm{Ca}-786, \mathrm{Si}-240$ \\
2 & $\mathrm{Ca}-393, \mathrm{Si}-120$ & $\mathrm{Ca}-393, \mathrm{Si}-120$ & $\mathrm{Ca}-393, \mathrm{Si}-120$ & $\mathrm{Ca}-1179, \mathrm{Si}-360$ \\
3 & $\mathrm{Ca}-393, \mathrm{Si}-120$ & - & - & $\mathrm{Si}-47.1$ \\
4 & $\mathrm{Si}-47.1$ & $\mathrm{Si}-47.1$ & $\mathrm{Si}-94.2$ \\
5 & $\mathrm{Si}-47.1$ & $\mathrm{Si}-47.1$ & $\mathrm{Si}-47.1$ & $\mathrm{Si}-141.3$ \\
6 & $\mathrm{Si}-47.1$ & & & -14 \\
\hline
\end{tabular}

From each plot 3 rows were harvested. During harvest the parts of beet plants with lives were cutout by hand, leaves were weighed. Roots were dug up, cleaned, counted and weighed.

The representative samples of roots for the technological root quality determination were collected during the harvest day from each plot. Sucrose, alphaamino-nitrogen, sodium and potassium content were determined with the Venema Automation beet-analyzing system by Kutno Sugar Beet Breeding Ltd. in Straszków (Poland). Based on obtained results, according to Buchholz et al. (1995) we were able to calculate: biological sugar yield $(\mathrm{t} / \mathrm{ha})$; loss of sugar productivity (\%); standard molasses loss (\%); technological sugar yield (t/ha); the refined sugar content $(\%)$. The experimental data were statistically analyzed using one way and two way analysis of variance and means were compared using LSD, with the level of significance $\alpha=0.05$. Statistical analyses were performed in the SAS 9.1 program (Cary, 
USA) using the GLM procedure. The basic statistics i.e. coefficients of variation, and range of variables were calculated.

\section{RESULTS AND DISCUSSION}

Field plant density during harvest was higher in 2014 (97.1 thousand of plants/ha) than in 2013 (88.4 thousand of plants/ha) (Table 4). However the number of plants was proper each year and consistent with the recommendations of many authors (Cakmakci et al. 1998, Campbell 2002,
Jafarnia et al. 2013). The two years average root yields years were varied from 90.6 to $105.3 \mathrm{t} / \mathrm{ha}$, respectively to the fertilization variant. In comparison with the control (variant 0) foliar fertilization with calcium and silicon resulted in $12.6 \%$ increase of root yield as average and was varied from 10.4 to16.2\% relatively to applied dose. At the same time foliar fertilization with silicon (without calcium) resulted in $14.5 \%$ increase of root yield as average and was varied from 13.7 to $15.9 \%$ relatively to applied dose.

Table 4. Average sugar beet yields and quality traits of roots and LSDs as the effect of silicon foliar fertilization on in 2013-2014

\begin{tabular}{|c|c|c|c|c|c|c|c|c|c|}
\hline \multirow{2}{*}{ Year (B) } & \multicolumn{7}{|c|}{ Foliar fertilization variant (A) } & \multirow{2}{*}{ Average } & \multirow{2}{*}{ LSD } \\
\hline & $\mathbf{0}$ & 1 & 2 & 3 & 4 & 5 & 6 & & \\
\hline \multicolumn{10}{|c|}{ Plant density during harvest, thousands of plants per ha } \\
\hline 2013 & 86.5 & 86.1 & 92.7 & 89.9 & 88.5 & 82.3 & 93.1 & 88.4 & $6.8^{*}$ \\
\hline 2014 & 102.8 & 99.3 & 95.1 & 95.5 & 96.2 & 95.8 & 95.1 & 97.1 & ns \\
\hline Average & 94.6 & 92.7 & 93.9 & 92.7 & 92.4 & 89.1 & 94.1 & - & $\mathrm{A}=\mathrm{ns} ; \mathrm{B}=3.0^{*}$ \\
\hline \multicolumn{10}{|c|}{ Roots yield, t/ha } \\
\hline 2013 & 94.4 & 122.2 & 111.1 & 110.3 & 111.8 & 120.2 & 113.1 & 111.8 & $19.1 *$ \\
\hline 2014 & 86.9 & 88.5 & 90.3 & 89.7 & 94.8 & 89.7 & 92.9 & 90.4 & ns \\
\hline Average & 90.6 & 105.3 & 100.7 & 100.0 & 103.3 & 105.0 & 103.0 & - & $\mathrm{A}=11.5^{*} ; \mathrm{B}=6.2^{*}$ \\
\hline \multicolumn{10}{|c|}{ Yield of leaves, $t / h a$} \\
\hline 2013 & 38.7 & 35.8 & 36.2 & 40.9 & 39.0 & 30.8 & 39.8 & 37.3 & $6.0^{*}$ \\
\hline 2014 & 40.8 & 36.7 & 42.3 & 42.3 & 44.3 & 44.0 & 40.8 & 41.6 & ns \\
\hline Average & 39.8 & 36.2 & 39.2 & 41.6 & 41.7 & 37.4 & 40.3 & - & $\mathrm{A}=\mathrm{ns} ; \mathrm{B}=3.2^{*}$ \\
\hline \multicolumn{10}{|c|}{ Biological sugar yield, $\mathrm{t} / \mathrm{ha}$} \\
\hline 2013 & 17.7 & 22.9 & 20.8 & 20.5 & 21.1 & 22.2 & 20.9 & 20.9 & $3.7 *$ \\
\hline 2014 & 15.5 & 16.2 & 16.8 & 16.6 & 17.2 & 16.1 & 16.5 & 16.4 & ns \\
\hline Average & 16.6 & 19.6 & 18.8 & 18.5 & 19.1 & 19.2 & 18.7 & - & $\mathrm{A}=2.1^{*} ; \mathrm{B}=1.1^{*}$ \\
\hline \multicolumn{10}{|c|}{ Technological sugar yield, t/ha } \\
\hline 2013 & 15.4 & 20.1 & 18.2 & 18.1 & 18.5 & 19.2 & 18.2 & 18.2 & $3.2 *$ \\
\hline 2014 & 13.9 & 14.6 & 15.1 & 14.9 & 15.5 & 14.4 & 14.7 & 14.7 & ns \\
\hline Average & 14.7 & 17.3 & 16.7 & 16.5 & 17.0 & 16.8 & 16.5 & - & $\mathrm{A}=1.9^{*} ; \mathrm{B}=1.0^{*}$ \\
\hline \multicolumn{10}{|c|}{ Sucrose content, \% } \\
\hline 2013 & 18.7 & 18.8 & 18.7 & 18.6 & 18.9 & 18.4 & 18.5 & 18.6 & ns \\
\hline 2014 & 17.9 & 18.4 & 18.7 & 18.5 & 18.2 & 18.0 & 17.8 & 18.2 & $0.75^{*}$ \\
\hline Average & 18.3 & 18.6 & 18.7 & 18.5 & 18.5 & 18.2 & 18.1 & - & $\mathrm{A}=0.5^{*} ; \mathrm{B}=0.3^{*}$ \\
\hline \multicolumn{10}{|c|}{ Content of alpha-amino-nitrogen, $\mathrm{mmol}_{+} / \mathrm{kg}$} \\
\hline 2013 & 29.0 & 26.5 & 27.6 & 25.6 & 27.2 & 33.0 & 28.2 & 28.1 & $5.5^{*}$ \\
\hline 2014 & 14.6 & 17.3 & 16.3 & 16.0 & 15.9 & 20.4 & 19.2 & 17.1 & $3.7^{*}$ \\
\hline Average & 21.8 & 21.9 & 21.9 & 20.8 & 21.5 & 26.7 & 23.7 & - & $\mathrm{A}=3.3^{*} ; \mathrm{B}=1.8^{*}$ \\
\hline \multicolumn{10}{|c|}{ Content of potassium, $\mathrm{mmol}_{+} / \mathrm{kg}$} \\
\hline 2013 & 46.9 & 45.5 & 41.7 & 38.8 & 44.2 & 48.4 & 45.2 & 44.4 & $6.1^{*}$ \\
\hline 2014 & 29.1 & 30.6 & 33.3 & 31.0 & 29.6 & 29.3 & 30.8 & 30.5 & $3.2 *$ \\
\hline Average & 38.0 & 38.0 & 37.5 & 34.9 & 36.9 & 38.8 & 38.0 & - & $\mathrm{A}=3.2 * ; \mathrm{B}=1.7^{*}$ \\
\hline \multicolumn{10}{|c|}{ Content of sodium, $\mathrm{mmol}_{+} / \mathrm{kg}$} \\
\hline 2013 & 4.65 & 4.98 & 4.38 & 2.68 & 4.18 & 4.08 & 3.95 & 4.13 & $2.19 *$ \\
\hline 2014 & 2.88 & 2.23 & 2.53 & 2.38 & 2.53 & 2.85 & 2.80 & 2.60 & ns \\
\hline Average & 3.76 & 3.60 & 3.45 & 2.53 & 3.35 & 3.46 & 3.38 & - & $\mathrm{A}=1.1^{*} ; \mathrm{B}=0.59 *$ \\
\hline \multicolumn{10}{|c|}{ Content of refined sugar, $\%$} \\
\hline 2013 & 16.3 & 16.5 & 16.4 & 16.4 & 16.5 & 15.9 & 16.1 & 16.3 & $0.7 *$ \\
\hline 2014 & 16.0 & 16.5 & 16.8 & 16.6 & 16.3 & 16.0 & 15.9 & 16.3 & $0.8^{*}$ \\
\hline Average & 16.2 & 16.5 & 16.6 & 16.5 & 16.4 & 16.0 & 16.0 & - & $\mathrm{A}=0.5^{*} ; \mathrm{B}=\mathrm{ns}$ \\
\hline
\end{tabular}

In previous studies Artyszak et al. (2014) and Artyszak et al. (2015) obtained respectively $13.1 \%$ and $21.8 \%$ increase of root yields as the effect of calcium and silicon foliar fertilization in two application times. Leaves' yield was similar in every variants $(36.2-41.7 \mathrm{t} / \mathrm{ha})$. This result is inconsistent compared to earlier study of Artyszak et al. (2014) where these authors observed $21.0 \%$ leaves' yield increase after double spraying with calcium and silicon compared with the control variant. Foliar fertilization in both silicon with and without calcium resulted in increase of biological and technological sugar yield. In the case of biological sugar yield obtained increase was $14.3 \%$ as two years average for silicon with calcium fertilization and was varied from 11.4 to $18.1 \%$ relatively to applied variant. Silicon without calcium resulted in $14.5 \%$ increase and was respectively varied from 12.7 to $15.7 \%$. Similarly in the case of technological sugar yield obtained increase was $13.5 \%$ as two years average for silicon with 
calcium fertilization and was varied from 12.2 to $17.7 \%$ relatively to applied variant. Silicon without calcium resulted in $14.0 \%$ increase and was respectively varied from 12.2 to $15.6 \%$. In previous Artyszak et al. (2014) studies the authors observed $15.5 \%$ increase of biological sugar yield and $17.7 \%$ increase of technological sugar yield as the effect of two times calcium and silicon foliar fertilization. In another studies on calcium and silicon fertilization Artyszak et al. (2015) observed respectively $24.4 \%$ and $24.8 \%$ increase of biological and technological sugar yield. Similarly the beneficial effects of silicon and calcium (Herbagreen Basic) foliar fertilization found: Kara and Sabir (2010) in grape, Ugrinović et al. (2011) in lettuce, Weihrauch et al. (2011) in chop and Trawczyński (2013) in potato.

The technological root quality estimated by such traits like: sucrose, alpha-amino-nitrogen (except for variant 5), potassium and refined sugar content, were not modified significantly by foliar fertilization variants in comparison with the control - variant 0 . However a tendency for sodium content decrease (significant in variant 3) was observed. In earlier studies Artyszak et al. (2014) observed a significant decrease of alpha-amino-nitrogen content and tendency for decrease of sodium and potassium content as the result of calcium and silicon foliar fertilization. From every quality root traits the smallest variability were found for content of sucrose and refined sugar and the highest variability for molassigenic components (amino-alpha-nitrogen, potassium and sodium) content (Table 5). From every compared foliar fertilization variants the smallest variability of root yield, biological and technological sugar yields was observed in variant 2. In contrast Artyszak et al. (2014) obtained similar $\mathrm{CV}$ values for these traits regardless of the fertilization variant.

Table 5. Range (min and max) and variation coefficients (CV) of plant density during harvest, yield and quality traits of roots in 2013-2014

\begin{tabular}{|c|c|c|c|c|c|c|c|c|c|c|}
\hline \multirow{2}{*}{ Variant } & \multirow{2}{*}{$\begin{array}{l}\text { Plant density during } \\
\text { harvest (thousands of } \\
\text { plants per ha) }\end{array}$} & \multicolumn{4}{|c|}{ Yield (t/ha) } & \multirow{2}{*}{$\begin{array}{c}\text { Sucrose, } \\
\%\end{array}$} & $\begin{array}{c}\text { Alpha- } \\
\text { amino- } \\
\text { nitrogen }\end{array}$ & $\mathbf{N a}$ & \multirow[t]{2}{*}{$\mathbf{K}$} & \multirow{2}{*}{$\begin{array}{r}\text { Refined } \\
\text { sugar, \% }\end{array}$} \\
\hline & & Roots & Leaves & $\begin{array}{l}\text { Biological } \\
\text { sugar }\end{array}$ & $\begin{array}{c}\text { Technological } \\
\text { sugar }\end{array}$ & & \multicolumn{2}{|c|}{$\mathrm{mmol}_{+} / \mathrm{kg}$} & & \\
\hline \multicolumn{11}{|c|}{ Minimum } \\
\hline 0 & 83.3 & 77.0 & 33.1 & 14.6 & 12.9 & 17.1 & 12.6 & 2.00 & 27.2 & 15.1 \\
\hline 1 & 81.9 & 75.4 & 25.7 & 14.0 & 12.6 & 18.0 & 16.1 & 2.00 & 28.1 & 16.1 \\
\hline 2 & 81.9 & 67.1 & 32.2 & 13.2 & 11.9 & 18.1 & 13.7 & 2.40 & 30.8 & 15.6 \\
\hline 3 & 81.9 & 75.3 & 34.5 & 14.1 & 12.8 & 17.9 & 10.9 & 2.20 & 29.8 & 15.9 \\
\hline 4 & 83.3 & 88.4 & 33.9 & 16.2 & 14.6 & 17.8 & 13.5 & 2.20 & 27.8 & 15.6 \\
\hline 5 & 75.0 & 87.2 & 26.8 & 15.5 & 13.9 & 17.4 & 15.9 & 2.20 & 25.6 & 15.2 \\
\hline 6 & 87.5 & 90.9 & 34.3 & 15.8 & 13.9 & 17.4 & 14.4 & 2.00 & 28.0 & 15.3 \\
\hline \multicolumn{11}{|c|}{ Maximum } \\
\hline 0 & 105.6 & 108.6 & 45.9 & 20.4 & 17.7 & 19.1 & 31.3 & 5.10 & 50.2 & 16.8 \\
\hline 1 & 101.4 & 151.9 & 48.1 & 28.0 & 24.4 & 19.1 & 31.6 & 8.20 & 53.9 & 16.9 \\
\hline 2 & 105.6 & 120.2 & 55.3 & 22.8 & 20.1 & 19.7 & 31.0 & 7.40 & 44.6 & 17.7 \\
\hline 3 & 102.8 & 114.3 & 48.7 & 21.5 & 19.0 & 18.9 & 27.4 & 3.40 & 45.6 & 17.0 \\
\hline 4 & 100.0 & 120.6 & 51.5 & 22.8 & 20.2 & 19.7 & 34.8 & 6.50 & 46.8 & 17.5 \\
\hline 5 & 102.8 & 143.3 & 51.3 & 26.9 & 23.1 & 18.8 & 37.7 & 5.00 & 53.9 & 16.3 \\
\hline 6 & 102.8 & 122.2 & 45.3 & 23.0 & 20.3 & 18.9 & 33.6 & 5.10 & 46.7 & 16.6 \\
\hline \multicolumn{11}{|c|}{$\mathrm{CV}, \%$} \\
\hline 0 & 9.8 & 13.3 & 11.8 & 14.2 & 13.2 & 3.6 & 36.3 & 31.0 & 25.5 & 3.2 \\
\hline 1 & 8.2 & 23.0 & 20.9 & 22.9 & 21.8 & 2.0 & 25.1 & 63.4 & 23.5 & 2.2 \\
\hline 2 & 7.5 & 17.2 & 20.3 & 17.0 & 16.4 & 3.0 & 29.0 & 48.1 & 14.5 & 3.8 \\
\hline 3 & 8.0 & 13.0 & 10.6 & 13.2 & 12.2 & 1.7 & 27.9 & 15.7 & 15.0 & 2.2 \\
\hline 4 & 6.4 & 11.1 & 13.7 & 13.6 & 13.3 & 3.4 & 34.8 & 42.1 & 22.3 & 3.7 \\
\hline 5 & 10.5 & 18.6 & 22.9 & 20.7 & 19.1 & 2.6 & 28.5 & 24.4 & 27.6 & 2.3 \\
\hline 6 & 5.1 & 11.4 & 10.6 & 13.6 & 12.9 & 2.7 & 26.9 & 30.6 & 21.1 & 2.6 \\
\hline
\end{tabular}

In summary, obtained results demonstrated that the use of silicon with and without calcium as foliar fertilization is advantageous for the sugar beet production. Such fertilization has a positive effect on sugar beet roots' yield without compromising their technological quality. Silicon fertilization showed the greatest benefits towards parameters as biological and technological sugar yields. However further research to determine the optimal silicon dose (with or without calcium), number and terms of applications under specific soil and weather conditions is still required.

\section{ACKNOWLEDGEMENTS}

The authors thank to: dr. Wacław Wiśniewski (KWS Polska Sp. z o.o.), Mirosław Łakomy, Adam Sitarski and Elżbieta Zając (KHBC Sp. z o.o.), Przemysław Hałasa 
(Intermag Sp. z o.o.), Edward Laskowski (Südzucker Polska S.A.), Witold Ferens, Grzegorz Grabowski and Justyna Jachacy for the assistance in conducting the experiments.

\section{LITERATURE CITED}

Amin, G.A., E.A. Badr and M.H.M Afifi. 2013. Root yield and quality of sugar beet (Beta vulgaris L.) in response to biofertilizer and foliar application with micronutrients. World Appl. Sci. J. 27:1385-1389.

Armin, M. and M. Asgharipour. 2012. Effect of time and concentration of boron foliar application on yield and quality of sugar beet. Am-Euras. J. Agric. \& Environ. Sci. 12:444448.

Artyszak, A. 2014. The efficiency of foliar boron fertilization of two sugar beet varieties. Part I. The yielding and technological quality of roots. Fragm. Agron. 31:7-18.

Artyszak, A., D. Gozdowski and K. Kucińska. 2014. The effect of foliar fertilization with marine calcite in sugar beet. Plant Soil Environ. 60:413-417.

Artyszak A., D. Gozdowski, and K. Kucińska. 2015. The effect of calcium and silicon foliar fertilization in sugar beet. Sugar Tech. 1. DOI 10.1007/s12355-015-0371-4

Buchholz, K., B. Märländer, H. Puke, H. Glattkowski and K. Thielecke. 1995. Neubewertung des technischen Wertes von Zuckerrüben. Zuckerindustrie. 120:113-121.

Cai K., D. Gao, J. Chen, and S. Luo. 2009. Probing the mechanisms of silicon - mediated pathogen resistance. Plant Signaling \& Behavior, 4:1-3.

Cakmakci, R., E. Oral and F. Kantar. 1998. Root yield and quality of sugar beet (Beta vulgaris L.) in relation to plant population. J. Agron. \&Crop. Sci. 180:45-52.

Campbell, L.G. 2002. Sugar beet quality improvement. In: Quality improvement in field crops. Basra A.S., L.S. Randhawa (ed.). The Haworth Press Inc. Binghamptom NY:395-413.

Casey W.H., Kinrade S.D., Knight C.T.G., Rains D.W., and E. Epstein. 2003. Aqueous silicate complexes in wheat, Triticum aestivum L. Plant, Cell Env., 27:51-54.

Černý, I., V. Pačuta, B. Adamčinová, K. Kováčik and M. Kozak. 2009. Production parameters of sugar beet influence of targeted Atonik application and Campofort leaf fertilizer. LCaŘ. 125:130-133.

Černý, I., V. Pačuta, R. Pospišil, P. Ondrišík and P. Kováčik. 2011. The effect of Atonic and Pentakeep-V on the production parameters of sugar beet and crop rotating in crop rotatio. LCaŘ. 127:174-177.

Fauteux F., W. Remus-Borel, J.G. Menzies, and R.R. Belanger. 2005. Silicon and plant disease resistance against pathogenic fungi. FEMS Microbiology Letters, 249:1-6.

Fawe A., M. Abou-Zaid, J.G. Menzies, and R.R. Belanger. 1998. Silicon - mediated accumulation of flavonoid phytoalexins in cucumber. Phytopathology, 885:396-401.

Gunes A., A. Inal, E.G. Bagci, and D.J. Pilbeam. 2007. Silicon mediated changes of some physiological and enzymatic parameters symptomatic for oxidative stress in spinach and tomato grown in sodic-B toxic soil. Plant Soil, 290:103-114.

Guntzer F., C. Keller, and J-D. Meunier. 2012. Benefits of plant silicon for crops: a review. Agron. Sustain. Dev., 32:201213.

Hellal, F.A., A.S. Taalab and A.M. Safaa. 2009. Influence of nitrogen and boron nutrition balance and sugar beet yield grown in calcareous Soil. Ozean Journal of Applied Sciences. 2:1-10.
Henriet C., X. Draye, I. Oppitz, R. Swennen, and B. Delvaux. 2006. Effects, distribution and uptake of silicon in banana (Musa spp.) under controlled conditions. Plant Soil, 287:359374.

Hradecká, D., J. Urban, L. Kohout, J. Pulkrábek and R. Hnilička. 2009. Utilization of brassinosteroids to stress control during growth and yield formation of sugar beet. LCa ̌r. 125:271273.

Jafarnia, B., R. Ghorbani, A.Z. Feizabady and A.R. Ghaemi. 2013. Impact of crop density and soil fertilization on sugar beet. Intl J Agri Crop Sci. 5:2991-2999.

Kara, Z. and A. Sabir. 2010. Effects of HerbaGreen application on vegetative developments of some grapevine rootstocks during nursery propagation in glasshouse. In: 2nd International Symposium on Sustainable Development, June 8-9, 2010, Sarajevo:127-132.

Kristek, A., B. Stojić and S. Kristek. 2006. Effect of the foliar boron fertilization on sugar beet root yield and quality. Agriculture-Scientific and Professional Review. 12:22-26.

Liang Y., H. Hua, Y-G. Zhu, J. Zhang, C. Cheng, and V. Romheld. 2006. Importance of plant species and external silicon concentration to active silicon uptake and transport. New Phytol., 172:63-72.

Ma J.F., N. Mitani, S. Nagao, S. Konishi, K. Tamai, T. Iwashita, and M. Yano 2004. Characterization of the silicon uptake system and molecular mapping of the silicon transporter gene in rice. Plant Physiol., 136:3284-3289.

Ma J.F., and N. Yamaji. 2006. Silicon uptake and accumulation in higher plants. Trends Plant Sci., 11:392-397.

Mitani N. and J.F. Ma. 2005. Uptake system of silicon in different plant species. J Exp. Botany, 56:1255-1261.

Pačuta, V. 2013. Influence of preparations containing bioactive substances on sugar beet quantity and production quality. LCaŘ. 129:228-230.

Pačuta, V. and M. Buday. 2013. Use of Beta-Liq-BQ and Trichomil-T biopreparations in sugar beet growing system. LCaŘ. 129:92-95.

Pačuta, V., I. Černý and J. Pulkrábek. 2013. Influence of variety and foliar preparations containing bioactive substances on root yield, sugar content and polarized sugar yield of sugar beet. LCaŘ. 129:337-340.

Pospišil, M., A. Pospišil and S. Sito. 2005. Foliar application of liquid fertilizer Fertina B to sugar beet. LCaŘ. 121:174-177.

Raven, J.A. 2003. Cycling silicon - the role of accumulation in plants. New Phytol., 158:419-421.

Sacała, E. 2009. Role of silicon in plant resistance to water stress. J. Elem. 14:619-630.

Trawczyński, C. 2013. The effect of foliar fertilization of preparation Herbagreen on potato yield. Ziemniak Polski. 2:29-33.

Ugrinović, M., S. Oljača, M. Brdar-Jokanović, J. Zdravković, Z. Girek and M. Zdravković. 2011. The effect of liquid and soluble fertilizers on lettuce yield. Contemporary Agriculture - The Serbian Journal of Agricultural Sciences. 60:110-115.

Weihrauch, F., J. Schwarz and A. Sterler. 2011. Downy mildew control in organic hops: how much copper is actually needed? Proceedings of the Scientific Commission CIHIHB-IHGC, June 19-23, 2011, Lublin Poland:75-78.

Wróbel, S. and K. Domaradzki. 2006. Effect of combined foliar application of boron and manganese with herbicide on yield and chemical composition of sugar beet. Pam. Puł. 142:585593.

Wróbel, S. and K. Domaradzki. 2013. Combined foliar application of boron and manganese with herbicide in sugar beet cultivation. Zesz. Nauk. UP Wroc., Rol. CV. 594:71-80. 